\title{
Military Technology and Human Loss in Intrastate Conflict: The Conditional Impact of Arms Imports ${ }^{1}$
}

\author{
Accepted at the Journal of Conflict Resolution
}

\begin{abstract}
Though often conjectured, there is a lack of empirical evidence that international transfers of military technology render intrastate conflicts more violent. We address this question and argue that expansions in governments' ability to fight aggravate the lethality of war. However, we expect this effect to be conditioned by rebels' military endowments and their choice of tactics. Where rebels are weak, they avoid open combat and additional governmental arms imports have no effect on the number of casualties. In contrast, governmental arms imports cause human losses to multiply when rebels have achieved military parity or superiority and, as a consequence, use conventional combat tactics. This hypothesis is tested on the number of battle-related deaths in intrastate conflict, 19892011, using, for the first time, data on governmental imports of both major conventional weapons and small arms. Results support our propositions and are robust to instrumenting for imports of both types of weapons.
\end{abstract}

Key words: conflict intensity; civil war; military technology; balance of power; arms trade

Word count: 10.926 (includes text, abstract, acknowledgement, graphs/figures, bibliography)

\footnotetext{
${ }^{1}$ Authors' statement: We thank Simon Linder for helpful support, Nicholas Marsh for providing us with the NISAT small arms transfer data, and Siemon Wezeman for providing us with the SIPRI major conventional weapons trade data. We are grateful to Andreas Mehltretter, Eva Ziegler, the editor Paul Huth, two anonymous reviewers, and the audience at the Jan Tinbergen Conference 2019, The Hague, for helpful comments. All mistakes are our own.

Supplemental material: An online appendix and replication data for this article are available on the journal website.
} 


\section{Introduction}

International transfers of military hardware are frequently covered in the news and many reports criticize suppliers for providing arms to governments embroiled in violent domestic conflict or well-known for violations of human rights (see e.g. Knight 2017; Cecco 2018; Wilcken 2018). These normative concerns induce international organizations to take action, such as the United Nations with the Arms Trade Treaty (Garcia 2014). A growing literature examines whether multilateral measures actually constrain governments' arms transfer decisions (Blanton 2000, 2005; Perkins and Neumayer 2010; Erickson 2013; Schulze et al. 2017). Despite the attention to countries' decision to sell weapons to other governments, the underlying causal claim that arms imports fuel and intensify violence has received scant consideration in the scholarly literature. To the best of our knowledge, there is only one quantitative study that examines how the import of military technology affects the intensity of armed conflict (Moore 2012). We show below that even these results are not reliable. We thus face a surprising deficit of knowledge about whether and how transfers of military technology increase the casualty numbers of intrastate conflicts.

In our view this is due to a lack of proper theorizing of how - and under which strategic circumstances - such transfers contribute to intensified fighting ${ }^{1}$. We argue that a conflict's general balance of power crucially moderates whether additional governmental fighting ability in the form of imported arms increases conflict intensity. Inflows of governmental military hardware are expected to make conflict more lethal only when rebels are militarily equal or stronger. To detect this conditional effect, we interact rebels' relative military strength at time $t$ with arms imports at time $t$. We are thus able to separate the effect of the general constellation of military might from that of additional governmental investments in the ability to fight and kill.

Theoretically, we build on recent studies that emphasize the effect of technologies of rebellion on conflict (Kalyvas and Balcells 2010; Balcells and Kalyvas 2014) to develop the mechanism underlying the expected conditional effect of arms imports. We focus on how the type of combat observed in a conflict is determined by the balance of power between the belligerents. Militarily weaker rebels will employ guerrilla and terrorist tactics, thus trying to avoid open clashes with government forces, whereas equal and stronger ones will usually also employ conventional modes of warfare. This means that government forces need to counter these challenges with different tactics and military technology. When facing weaker rebels, their superior ability to fight is already ensured and the issue is finding and identifying enemy combatants. Additional military technology does not help in doing so and arms imports thus 
should have no effect on the intensity of conflict. When rebels are militarily equal or even superior to government forces, arms imports in contrast provide a relevant boost to the government's ability to wage war, allowing it to attack the enemy with increased force and engage in decisive battles. Therefore, arms imports should increase the intensity of fighting and thus casualty numbers in these cases. In line with this framework, we expect that a larger volume of arms imported by the government will cause the number of casualties to increase only in conflicts where the challenging group is at least as strong as the government. High amounts of imported weapons by governments fighting a comparatively weak challenger will not substantially change the balance of power or help in counterinsurgency operations and therefore should have no effect on the intensity of combat. Employing a time-series crosssection design that allows us to account for temporal dynamics, we use data on the governmental import of both major conventional weapons and, for the first time in a quantitative study of armed intrastate conflict, small arms to test this proposition.

We find considerable evidence for our hypothesis. This finding holds when we employ instrumental variables to account for potential endogeneity between arms imports and fighting intensity that may arise as governments import weapons in anticipation of conflict escalation. We use imports of major conventional weapons unsuited for intrastate conflict to instrument for imported major conventional weapons usable in counterinsurgency (see Pamp et al. 2018). And we use imported civilian sporting weapons to instrument for the import of military small arms. Results from these models corroborate the conditional effect of arms imports on conflict intensity. Counterintuitively, there is little support for a non-conditional conflict-intensifying effect of weapons inflows as found by the only existing earlier study.

We proceed by shortly discussing the state of the literature on the determinants of conflict intensity in the next section before formulating our theoretical expectations in section three. Section four discusses the choice of method, data and variables. We report on the analysis, results and interpretations in section five. Section six provides a conclusion and delineates the consequences of our findings for the further analysis of conflict intensity and for political responses to deadly intrastate conflict.

\section{Existing Literature on Conflict Intensity}

Much of the previous literature on the extent of human loss in intrastate conflict has examined how macro-level attributes of the conflict country affect the number of casualties. There, it is argued that democracies and countries with larger ruling coalitions fight less intense wars because they have more constraints on the use of force against rebels and are better able to coopt them (Lacina, 2006; Heger and Salehyan, 2007). Conflict intensity is also found to 
increase with the degree of poverty (Chaudoin et al., 2017) and income inequality (Lu and Thies, 2011), pointing to the opportunity costs of participating in rebellion as a driver of fighting intensity. This is substantiated by evidence that shocks to commodity prices and agricultural productivity increase the intensity of fighting (Bazzi and Blattman, 2014; Dube and Vargas, 2013; Gawande et al., 2017; Wischnath and Buhaug, 2014). Economic opportunities that increase rebels' utility of and ability to finance fighting are similarly positively associated with conflict intensity (Angrist and Kugler, 2008; Daxecker and Prins, 2017; Dube and Vargas, 2013; Lujala 2009). Notably, the effect of ethnic cleavages is less clear: Eck (2009) finds that ethnic conflicts are more likely to escalate to full civil wars but numerous studies report negative effects of ethnic heterogeneity on conflict intensity (Balcells and Kalyvas, 2014; Lacina, 2006; Lujala, 2009; Moore, 2012).

We also face mixed results regarding the effect of military capability: Quantitative studies generally control for an ordinal measure of rebel strength, finding that weaker rebels either fight in less intense conflicts (Heger and Salehyan, 2007; Lujala, 2009) or that no relationship exists (Hultman et al., 2014; Hultman and Peksen, 2017). Other studies test whether measures of the governments' military capability are associated with casualty numbers but find that conflict intensity cannot be explained by governmental military quality (Lacina, 2006) or regional variations in the manpower of the security forces (De Juan and Pierskalla, 2015). However, there is evidence that externally induced changes in actors' fighting resources affect conflict intensity as both support by private military and security companies for the government and external support to rebels boosts the number of casualties (Balcells and Kalyvas 2014; Petersohn, 2017).

Balcells and Kalyvas (2014) emphasize the role of military technology by typologizing civil wars based on the belligerents' technological endowments and arguing that wars in which both sides have major conventional weapons $(\mathrm{MCW})$ at their disposal are deadlier than asymmetrical wars where only the government employs MCW. This proposition that weapons technology affects the type and lethality of warfare is additionally strengthened by findings that arms embargoes indeed reduce conflict intensity (Hultman and Peksen, 2017) while MCW imports increase it (Moore, 2012).

More specifically, Moore (2012) argues that MCW transfers to insurgents are positively related to the number of battle fatalities in the following years of conflict. He also finds that weapons imported by the government during and in the five years before conflict increase human loss. However, the latter finding results from a coding mistake. The values of the main independent variable in the relevant specifications are not the natural logarithm of 
governmental arms imports but actually the logarithm of the already logged arms imports during the conflict ${ }^{2}$. After correcting this, the effect of governmental arms imports becomes statistically insignificant. Whereas this is the only contribution to quantitatively analyse the effect of MCW on conflict intensity, a considerable amount of qualitative literature argues that small arms increase casualty numbers (e.g. Bourne, 2007; Greene and Marsh, 2012; Mehrl, 2017; Sislin and Pearson, 2006). However, generalizable quantitative evidence on the impact of arms imports on conflict intensity is lacking. Results concerning their effect on the onset and duration of armed conflict indicate that a re-examination of this important phenomenon can produce important insights (Craft and Smaldone, 2002; Mehltretter et al., 2019; Pamp et al., 2018). In the following, we address this by delineating how governmental arms imports increase human loss in armed conflict.

\section{Theory: Linking Military Technology and Conflict Intensity}

Laia Balcells and Stathis Kalyvas (2010, 2014) offer a major contribution to our understanding of armed conflict by emphasizing the role belligerents' tactics and military technology play in civil war. They also make clear that armed conflicts are, at their core, strategic contests between at least two parties in conflictuous interaction, indicating that a monadic view of arms imports as simply increasing one party's ability to fight and thus leading to more violence may be misleading. This dyadic conception of conflict (for this fundamental change in the perspective on intrastate conflicts see also Buhaug et al., 2008; Cederman and Gleditsch, 2009) implies that military capability is a relational concept, comparing the belligerents' absolute number and quality of material and immaterial fighting resources, and that how additional military technology affects conflict should depend on how the interaction between the parties is structured. In a purely monadic view, the government obtaining additional weapons or troops increases its ability to fight and kill. But whether this is actually the case against a specific opponent is certainly moderated by belligerents' combat tactics and endowments. These vary with conflict parties' balance of power.

Armed intrastate conflicts can be classified into irregularly and conventionally fought ones. In irregular conflicts, rebels rely on terrorist and guerrilla tactics to attack their opponent while avoiding open clashes. They are dispersed in the region of conflict, mixed with the civilian population, hidden in rough terrain, and highly mobile. In contrast, conventionally fought wars are similar to interstate warfare as they features elaborate military campaigns and open combat utilizing heavy weaponry (Butler and Gates, 2009; Kalyvas and Balcells 2010; Balcells and Kalyvas, 2014). While irregular tactics have generally been described as a weapon of the weak available to small and outgunned groups, conventionally fought conflicts 
require rebels to have sufficient military technology and manpower to match up with a government's full military might. Thus, weaker rebels have been argued to pre-eminently employ irregular tactics and avoid open confrontations with more powerful government foes whereas those with higher military endowments should be more able to openly attack the enemy while also being much less able to hide from it than weak insurgents (Balcells and Kalyvas, 2014; Buhaug 2010; Butler and Gates, 2009; Fearon, 2007; Wright, 2016).

Due to this difference in the tactics used by differently endowed rebels, governments also employ different military countermeasures to combat them. Counterinsurgency forces dealing with an enemy using irregular tactics mainly need to identify and selectively target insurgent individuals living among the civilian population. Raids against such individuals usually aim to only hurt or kill the few targeted enemy combatants but not the civilian bystanders they are surrounded by (Galula, 2006: ch.7; Kiras, 2016: 185-187). Information is the key good in combating weak insurgents and counterinsurgents hence must be able to gather it, interact with the civilian population, find potential collaborators, and identify potential cleavages among insurgents (Galula, 2006: ch.7; Kalyvas 2006: ch.7; Lyall, 2010). Counterinsurgents seek to eliminate insurgent targets to signal their ability and determination to track them down and inflict costs on rebels but should do so selectively and while avoiding mass casualties as these would turn the civilian population against them and increase insurgents' ability to mobilize $^{3}$ (Kalyvas 2006, ch.6; Wright et al. 2017).

When opponent forces are up to par with the incumbent government's military, counterinsurgency is markedly different as it is now facing a considerable and more conventional military organization instead of armed individuals dispersed among a crowd of civilians. Targeting such an organization is easier while success in combat events against it is less certain than in targeted raids against weak insurgents. This means that effective counterinsurgency against weaker rebels is highly dependent on finding the enemy whereas against more capable ones the issue is not finding but fighting them (Butler and Gates 2009; Kalyvas and Balcells 2010). Government forces facing a strong challenger thus engage in combat to signal strength and determination by inflicting as large costs on their challengers as possible while also looking to e.g. (re-)capture rebel-held territory. The relative capability and tactics used by rebels thus critically shape the tasks of government forces fighting them and this should also determine whether military technology inflows can be expected to have any influence on the dynamics of violence.

Acquiring military technology is arguably the most readily available and effective way of increasing fighting power in the short term. Because most governments fighting intrastate 
conflicts and all but very few insurgent groups are unable to produce weapons themselves, most actors must import them to acquire new military technology. The delivery of new weapons means an instant boost to the receiver's ability to wage conventional war. For incumbents facing an equally or more capable opponent, it means an increased opportunity to attack enemy positions and engage in decisive battlefield engagements featuring heavy fighting. Small arms can be used to arm additional infantry and hence increase one's manpower. Major conventional weapons create or increase the ability to carry out highly lethal combined armed forces operations (Caverley and Sechser, 2017). Both the delivery of new small arms and major conventional weapons can thus be expected to increase the intensity of military engagements with strong insurgents.

Receiving new weapons also boosts the absolute fighting power of governmental forces facing a weak insurgent organization. But such shifts should have no differential effect on conflict intensity. Governmental forces already enjoy an unassailable lead in military capabilities over the insurgents. Hence, a qualitative or quantitative surge in their weaponry does not change the situation on the ground in a way that makes intensive military engagements deadlier or more likely. When government forces are militarily much more capable than their insurgent opponents, their main issue is not defeating enemy fighters in open combat but locating them as rebels will try to evade such engagements. In these situations, counterinsurgent forces need to gather information on rebel whereabouts. Obtaining additional weaponry should not help with this task. Arms deliveries to incumbent forces fighting a weak insurgent organization should hence not impact conflict intensity. Together, these arguments imply a conditional relationship between arms imports and conflict intensity, leading to the following hypothesis:

Hypothesis: The effect of arms imports by governments fighting an internal conflict is conditional on the balance of military power in the conflict. When rebel forces are at least as strong as the government, governmental arms imports increase the number of conflict casualties, otherwise they do not.

However, one issue with this proposition is that governments as strategic actors may anticipate increased fighting intensity and therefore import $\mathrm{arms}^{4}$. This would induce endogeneity and present a serious challenge to our hypothesis. To tackle this problem, we adopt an instrumental variables strategy and propose two instruments that provide exogenous variation in governmental imports of MCW and small arms, respectively. In the case of major conventional weapons, we follow a recent suggestion and use imports of MCW that cannot be used in intrastate warfare as an instrument for imports of MCW that can (Pamp et al. 2018). 
For small arms, we propose an entirely new instrumental variable. The import of civilian small arms such as sporting rifles should not affect conflict intensity but is closely linked to the import of small arms for military purposes. We thus employ civilian small arms imports as a source of exogenous variation in military small arms imports. The next section discusses this instrumental variables strategy in more detail but first generally describes how we test our expectation.

\section{Data and Methodology}

We use the UCDP Battle-Related Deaths Dataset, Version 5.0 (Melander et al., 2016) to measure our dependent variable, conflict intensity, and hence define it as the yearly number of battle-related deaths in conflicts with a minimum of 25 such deaths per year. While this dataset begins only in 1989 and thus has the disadvantage of a rather short maximum period of observation, its data quality appears to be more satisfactory than that of the PRIO battle deaths data. There, $54 \%$ of observations are either based on limited sources or no other sources than the differentiation between wars and minor armed conflicts coded in the UCDP / PRIO Armed Conflict Data (Lacina, 2009: 5). While we could extend our analysis of the impact of government imports of MCW on conflict intensity back to the mid-1970s by using the PRIO battle deaths dataset as data on MCW transfers is available for the whole postWWII period and data on rebel strength begins in 1976, we choose to prioritize data quality over the length of our period of observation. This also seems reasonable due to data on small arms transfers only being available from 1992 on. As can be seen in table one, the average conflict year sees 808 battle deaths, casualty counts range from 25 to 30633. Comparable to Lacina (2006), we log-transform our measure of battle deaths, the dependent variable of the analysis is thus the natural logarithm of battle-related deaths that have occurred in year $t$ of conflict $i$.

Our models include two key independent variables, arms transfers to governments and the balance of power between the conflict parties. We use two different sources of data to measure arms transfers: on one hand, we rely on data collected by SIPRI (2017) to account for international transfers of major conventional weapons, their volume is ascertained using Trend Indicator Values (TIVs) describing the traded weapons' strategic value as opposed to the price paid for them ${ }^{5}$. On the other hand, we are the first to also analyse how small arms influence conflict dynamics as we use data collected by the Norwegian Initiative on Small Arms Transfers (PRIO, 2017) that indicate the yearly financial volume of imported small arms transfers in standardized US\$. We construct a pair of variables gauging the volume of 
weapons delivered at $t$, Import: $M C W_{t}$ measures the import of major conventional weapons at $t$ while Import: Small Arms $s_{t}$ does the same for small arms. On average, governments in our dataset import MCW worth 374.75 TIV and small arms worth 23,100,000 US\$. There is however some relevant variation both between and within government's import numbers. To ease interpretation, arms import variables are also log-transformed. Due to the NISAT data only being available for the years 1992-2012 and the coverage of the Non-State Actor data ending in 2011, we analyse the period 1992-2011 in our main analyses. As data on MCW is available for a longer period, we also report analyses concerning only this type of weapons for the period 1989-2011 in the appendix ${ }^{6}$.

We also need a measure of relative military strength in a conflict to test our hypothesis. For this, we use a variable taken from the Non-State Actor dataset (Cunningham et al., 2009, 2013) that describes the rebels' strength as compared to government forces and is based on each sides' estimated troop sizes while not taking into account their endowment with military technology ${ }^{7}$ (Cunningham et al., 2013: 522). The original variable uses ordinal scaling and has five categories ranging from cases where insurgents are much weaker than the state forces to ones where they are much stronger. To properly measure our theoretical expectations, we collapse it into a dummy variable Rebel Strength: Equal or Higher coded 1 if insurgents achieve parity with or are stronger than their opponent and 0 if otherwise. The majority of cases - ca. 90\% - are coded as conflicts involving weak insurgents but there is some relevant within variation as insurgent groups gain or lose relative capacities. While this data set covers a majority of conflict years in the UCDP Battle-related Deaths Data, it does not cover all of them, lacking information on 28 conflict years from 17 different conflicts ${ }^{8}$. We interact this variable with Import: $M C W_{t}$ and Import: Small Arms $s_{t}$, respectively, to test our expectation regarding a conditional effect of arms transfers. Summary statistics for these variables are presented in table one.

\section{Table one approximately here}

Control variables included in all specifications are selected to closely follow the previous studies of conflict intensity discussed above. We control for the population size of the country a conflict is taking place in using the population variable from Version 6.0 Beta of Gleditsch's (2002) data. A variable from the same source is employed to control for a country's economic situation, using the Real GDP per capita measure. Both measures are logarithmized, the per capita measure of GDP is also lagged one year to tackle endogeneity. A country's political order is controlled for using data provided by the Polity IV Project (Marshall et al., 2016). In 
contrast to Lacina (2006) among others, we do not dichotomize the data but leave in its original ordinal scaling with 21 values. A variable from the Ethnic Power Relations Dataset (Vogt et al., 2015) is used to measure the fraction of a country's total population belonging to politically relevant ethnicities that belongs to marginalized groups. In contrast to the measures of ethnic fractionalization and polarization employed in previous studies of conflict intensity, this variable only accounts for members of groups whose group identity is in fact politically salient as opposed to including even the tiniest ethnicities that have never shown any potential for the organization of political - or insurgent - action. For this reason, it may be better suited to capture the role of ethnicity in determining conflict intensity. We further include a variable indicating how many years of conflict have passed before a given observation to account for the possibility that e.g. years at the start or end of a conflict may be more intense than ones at the middle; it also corresponds to the variable measuring conflict duration included in studies that use whole conflicts as observations (Lacina, 2006; Lujala, 2009). The measure is coded from the UCDP Armed Conflict Data.

In carrying out a panel analysis of the intensity of conflicts active in the period 1992 to 2011, we have to check for non-stationarity, serial autocorrelation, and unit heterogeneity. To test for non-stationarity, we employ a Fisher-type test that runs an Augmented Dickey-Fuller test on every separate panel and combines their results in one single p-value (Choi 2001). Its results reject the null hypothesis that the panel is non-stationary. To test for serial autocorrelation over time, we run fixed-effects estimations for all specifications where each model's lagged residuals are regressed on its residuals. As the coefficient showing the correlation between residuals and lagged residuals considerably differs from zero in all cases, it appears sensible to include some lags. Following De Boef and Keele (2008), we run regressions including lagged variants of all dependent and independent variables to find out which lags to include; those that have a significant effect there will then be included in the further analysis. This step leads us to include a one-year lag of the dependent variable. We test for unit heterogeneity, i.e. whether unit-specific errors are unequal to zero, and it becomes apparent that we have to use a fixed-effects estimator in all models as F-Tests consistently reject the null hypothesis of unit-specific errors equaling zero (Baum, 2006: 221f).

We hence include one-year lags of the dependent variable battle deaths and conflict-fixed effects in all specifications. The complete specified model thus takes the form 
1) Battle deaths $s_{i, t}$

$=\alpha_{i}+\beta_{1}$ Rebel Strength $h_{i, t}+\beta_{2}$ Import: $_{\text {MCW }}$ i,t

$+\beta_{3}$ Import: Small Arms $s_{i, t}+\beta_{4}$ Rebel Strength $*$ Import: $M C W_{i, t}$

$+\beta_{5}$ Rebel Strength $*$ Import: Small Arms $s_{i, t}+\beta_{6}$ Battle deaths $_{i, t-1}$

$+\boldsymbol{\beta} \boldsymbol{X}+\varepsilon_{i, t}$.

There, we are especially interested in the coefficients $\beta_{2}$ to $\beta_{5}{ }^{9}, \alpha_{i}$ is the conflict-specific intercept, $\boldsymbol{X}$ is a vector of controls, and $\varepsilon_{i, t}$ represents the error term. In using interaction terms, we follow current best practice (Brambor et al., 2006: 64) by individually including the variables constituting the interaction term, refraining from interpreting these as if they were unconditional effects, and presenting margins plots for the relevant interaction results.

One key weakness of this approach could be that it ignores potential endogeneity between arms imports and conflict intensity. Governments may import arms because they anticipate increased fighting intensity, implying possible endogeneity between our dependent and independent variables of interest. To address this concern, we use two instrumental variables. In the case of major conventional weapons, we take up an instrument recently proposed to study the relationship between arms imports and civil war onset. Pamp and co-authors argue that only some MCW, namely "aircraft, armoured vehicles, artillery and missiles", are usable in intrastate conflict whereas other weapons systems, i.e. "air-defence systems, antisubmarine weapons, satellites and ships", can hardly be employed in these conflicts and should thus not be acquired in anticipation of them (2018: 436f.). For our purpose, the former types of MCW may be imported for the goal of carrying out a decisive military campaign and thus in anticipation of increased casualties. In contrast, the latter types will not help in such a campaign and their import should thus not result from such anticipation. Imports of both types of MCW are empirically strongly correlated as states balance their military portfolio (ibid.: 437). However, governments facing intensified conflict are forced to focus their investment in weapons that are useful for fighting civil wars. Portfolio balancing is thus temporarily disrupted, meaning that governments should not increase imports of the latter type to balance the imports of the former type that they made in anticipation of conflict. The exclusion restriction is hence fulfilled.

As a result, we can examine whether our findings are due to endogeneity by splitting up our measure of MCW imports into two variables that, respectively, measure the logged import of MCW related and unrelated to armed intrastate conflict and then use the latter to instrument for the former in fixed effects 2-Stage-Least-Squares models. Following Wooldridge (2012: 96ff.), the second stage for the complete specified model is given by 
2) Battle deaths $s_{i, t}$

$$
\begin{aligned}
& =\alpha_{i}+\beta_{1} \text { Rebel Strength } h_{i, t}+\beta_{2}{\text { Import } \widehat{\text { CW }} M C W_{l, t}} \\
& +\beta_{3} \text { Rebel Strength } \widehat{* I m p o r t:} \text { CWMCW } W_{l, t}+\beta_{4} \text { Battle deaths }_{i, t-1}+\boldsymbol{\beta}(\boldsymbol{X}) \\
& +\varepsilon_{i, t}
\end{aligned}
$$

while the first stage is given by

3) Import: $C W M C W_{i, t}$, Rebel Strength * Import: $C W M C W_{i, t}$

$$
\begin{aligned}
& =\gamma_{i}+\delta_{1} \text { Rebel Strength } h_{i, t}++\delta_{2} \text { Import }_{\text {NCWMCW }} \text { CW } \\
& +\delta_{3} \text { Rebel Strength } * \text { Import: NCWMCW } W_{i, t}+\delta_{4} \text { Battle deaths }_{i, t-1} \\
& +\boldsymbol{\delta}(\boldsymbol{X})+v_{i, t} .
\end{aligned}
$$

There, Import: $C W M C W_{i, t}$ represents imports of civil war-related weapons whereas Import: $N C W M C W_{i, t}$ represents the imports of weapons not usable in intrastate conflict. Note that we instrument for both Import: $C W M C W_{i, t}$ and its interaction with rebel strength using Import: NCWMCW Sørensen 2013; Wooldridge 2012: 144f.). $\alpha_{i}$ and $\gamma_{i}$ correspond to conflict-fixed effects, $\boldsymbol{X}$ is a vector of controls, and $\varepsilon_{i, t}$ and $v_{i, t}$ represent the error terms. Here, we are interested in the coefficients $\beta_{2}$ and $\beta_{3}$.

We proceed in a similar fashion to instrument for small arms imports. We separate small arms into those that are useful for counterinsurgency and those that are not, i.e. distinguish between military weapons and small arms for civilian usage. This latter category includes hunting weapons as well as rifles and handguns used in shooting sports. While we would expect military small arms to be used in combat action and thus affect conflict intensity, this is not the case for civilian small arms as their main users are civilians who should not participate in fighting. And in the cases that sporting weapons are used in combat, these should be weapons that have previously been in the country as rebels may collect hunting rifles from civilians before or during their insurgency but should not be able to access weapons that were freshly imported through government-regulated channels. However, there is also clear evidence that the import of military and civilian small arms is closely linked due to shared channels of acquisition (see Lebacher et al. 2019). Arms producers that have obtained market access in a receiver country for one type of small arms will also seek to use this access to sell their other products. A country that imports military small arms from a given company is thus likely to also import civilian weapons from this source at the same time. This implies that imports of 
civilian small arms are correlated with military small arms imports. But they otherwise do not affect conflict intensity, thus making their use as an instrumental variable for military small arms appropriate.

We thus also split up our measure of Small Arms imports into two variables that, respectively, measure the logged import of military and civilian small arms and use the latter as an instrument for the former in fixed effects 2-Stage-Least-Squares models. Here, the second stage is accordingly given by

2) Battle deaths $s_{i, t}$

$$
\begin{aligned}
& =\alpha_{i}+\beta_{1} \text { Rebel Strength } h_{i, t}+\beta_{2}{\text { Import: } M S A_{l, t}} \\
& +\beta_{3} \text { Rebel Strength*Import: } \text { MSA }_{l, t}+\beta_{4} \text { Battle deaths }_{i, t-1}+\boldsymbol{\beta} \boldsymbol{X}+\varepsilon_{i, t}
\end{aligned}
$$

while the first stage is given by

3) Import: $M S A_{i, t}$, Rebel Strength * Import: $M S A_{i, t}$

$$
\begin{aligned}
& =\gamma_{i}+\delta_{1} \text { Rebel Strength } h_{i, t}++\delta_{2} \text { Import }_{\text {CSA }} A_{i, t} \\
& +\delta_{3} \text { Rebel Strength } * \text { Import: } C S A_{i, t}+\delta_{4} \text { Battle death } s_{i, t-1}+\boldsymbol{\delta} \boldsymbol{X}+v_{i, t} .
\end{aligned}
$$

Import: $M S A_{i, t}$ represents imports of military small arms whereas Import: $C S A_{i, t}$ represents the imports of weapons for civilian use. As above, we instrument for the interaction of rebel strength and Import: $M S A_{i, t}$ by including the interaction Rebel Strength * Import: CSA $A_{i, t}$ and are again interested in the coefficients $\beta_{2}$ and $\beta_{3}$.

\section{Empirical Analysis}

We begin by analyzing the effect of imports of both small arms and MCW on conflict intensity as in equation 1); results are presented in table 2. Because there are no reliable studies yet that examine the unconditional effect of arms imports on conflict casualties, and in order to demonstrate the relevance of our theorized conditional effect, we begin by testing for an unconditional effect in Model 1. We then separately include the two interactions of Import: $M C W_{t}$ and Import:Small Arms $t_{t}$ with Rebel Strength in models 2 and 3, respectively. Model 4 includes both interactions.

\section{Table two approximately here}

Before turning to the results regarding our hypothesis, we shortly examine the unconditional effect of arms imports on conflict intensity as tested in model 1. Parts of the literature on how military technology affects conflict dynamics have formulated the idea that the increased availability of weapons would cause the death toll of intrastate conflicts to rise no matter the 
strategic situation of the conflict parties. Thus, we would expect positive effects for both Import: $M C W_{t}$ and Import: Small Arms $s_{t}$ here. The results in model 1 provide only partial support for these conjectures: the volumes of major conventional weapons imported by the government exhibit a significant and positive association with the number of battle-related deaths. This unconditional effect is, however, rather small as a $1 \%$ increase in the TIV-Value of MCW import corresponds to a $0.12 \%$ increase in battle deaths, i.e. 37 additional deaths. Imports of small arms show no separate statistical effect.

Our own hypothesis contends that arms imports to the government during an ongoing conflict actually have a heterogeneous effect that is conditional upon the relative military strength of the rebels the conflict is fought against. As arms transfers would not substantially change the balance of power in conflicts fought against weak challengers, the import of major conventional weapons should only escalate the intensity of conflicts involving highly capable rebels. Models 2 and 3 in table 2 support this proposition: Both interactive terms - Rebel Strength $x$ Import: $M C W_{t}$ and Rebel Strength $x$ Import:Small Arms $s_{t}-$ exhibit large positive coefficients that are significant at the $1 \%$-level whereas the constituent terms accounting for arms transfers to governments fighting weak challengers prove to be insignificantly related to the quantitative size of human loss. This means that in conflicts where rebels are weak, the import of additional weapons by the government plays no role in terms of its effect on casualties. This result is supported further by model 4 showing that even when included at the same time, Rebel Strength $x$ Import: $M C W_{t}$ remains significant on the 1\%-level while Rebel Strength $x$ Import:Small Arms $s_{t}$ is significant at the 5\%-level. Marginally decreased statistical significance is possibly due to collinearity with the other interaction term ${ }^{10}$. We concentrate on this model for further interpretation as it is the most complete and results are substantially identical.

Figure 1 presents the marginal effects of government arms imports conditional on rebel strength. Arms transfers to governments fighting weak rebels show no effect at all. Transfers to governments struggling with a military capable insurrection, on the other hand, have a clear positive effect on human losses and confidence intervals for these two cases stop overlapping where imports of MCW / small arms amount to more than $e^{4}=54.6 \mathrm{TIV} / e^{13}=442,413$ US\$. Each additional $1 \%$-increase in the TIV of imported MCW causes a $0.55 \%$ increase in conflict fatalities in model 4 while each $1 \%$-increase in the financial value of small arms causes an additional $0.25 \%$ increase in conflict fatalities.

Figure $1 a$ and $1 b$ approximately here 
What this means more substantially in terms of intensity is presented in table 3 , where we report the predicted casualty numbers for two import values of MCW and Small Arms, respectively, and how they depend on whether rebels have achieved parity. These import values are represented by the sample mean and the sample mean plus one standard deviation of the logged values ${ }^{11}$. The predictions illustrate that armed conflicts are generally more intense when rebels are at least equally endowed to the government forces but prone to escalate considerably due to increased governmental arms imports. Take Pakistan as an example where a robust, Taliban-aligned challenge escalated into a full-scale civil war in the late 2000s, causing 6303 battle deaths as recorded in our data ${ }^{12}$. At the same time, the government of Pakistan invested heavily in military technology, importing above average values of both small arms (33,136,303US\$) and MCW (1210 TIV). Using model 4 to generate a prediction of that conflict year's casualty number had Pakistan only imported sample mean values of arms, i.e. 90 TIV of MCW and 1,202,604US\$ of small arms, we arrive at only 607 estimated battle deaths. For the case of Pakistan, arms imports thus heavily contributed to bloodshed. Extending this counterfactual, the difference in predicted battle deaths between observed and mean imports would have been only 349 had Pakistan fought weak insurgents. Similar dynamics can be observed in Angola's war against UNITA and the Bosnian civil war of the early 1990s. In contrast, countries like Israel and India have imported substantial amounts of weapons during our period of observation but did not experience an increase in conflict intensity as both governments faced weak rebels. This further illustrates our result that, consistent with the hypothesis, arms imports during fighting have a conditional effect on the number of deaths in intrastate war that is positive and sizeable only in cases where insurgents are strong and indistinguishable from zero otherwise.

\section{Table 3 approximately here}

Until now, our analysis treats arms imports as exogenous. But as discussed above, this may be problematic because governments may increase their import volume when anticipating intensified fighting. To tackle this, we adapt an instrumental variables strategy. We use imports of MCW unrelated to internal conflict as a source of exogenous variation imports of in MCW that are related to internal conflict (Pamp et al. 2018) and similarly employ civilian small arms imports to instrument for imports of military small arms. The first- and secondstage results of these models are presented in the appendix where we also discuss instrument strenght. Substantively, these results are in line with those from our main analysis. The import of civil war-related $\mathrm{MCW}$, instrumented for using the import of MCW irrelevant for intrastate warfare, increase casualty numbers in conflicts where rebels have achieved at least parity but 
not in the ones where a militarily dominant government fights weaker rebels. But the size of this effect is smaller than in the main analysis as each additional 1\%-increase in the TIV of imported $\mathrm{MCW}$ is associated with a $0.15 \%$ to $0.21 \%$ increase in conflict fatalities. And while the import of military small arms, instrumented for with civilian small arms, has a small but significant effect on conflict intensity even in conflicts against weak rebels, this effect doubles in size to $0.25 \%$ for conflicts where rebels have achieved parity. Weak instrument tests indicate that our instrument for MCW imports may be a weak one but the results of additional, weak instruments-robust tests provide further support for our theoretical argument. The instrumental variables analysis thus substantiates our claim that governmental arms imports aggravate the intensity of conflicts involving militarily capable rebels while adjusting for endogeneity ${ }^{13}$.

We now consider a number of further specifications of the models reported above to gauge how robust these effects are. Due to space constraints, we can only give a brief summary here and offer a more detailed account in the online appendix. First, our results may still be due to bias as we employ a lagged dependent variable alongside fixed effects. In this setup, the lagged dependent variable is correlated with the error term (Nickell, 1981). This results in bias of order $\frac{1}{T}$, meaning that short panels may be highly biased whereas the bias decreases in longer panels (Beck and Katz, 2011:342). Given that our panels are relatively short, we use difference and system GMM estimators (Arellano and Bond, 1991; Arellano and Bover, 1995; Blundell and Bond, 1998; see also Baum, 2006: 233f.; Roodman, 2009) to make sure that our findings are not a result of biased estimation. We replicate table 2 with each estimator and variably include time dummies (see Roodman 2009: 128). GMM results regarding the interaction terms between arms imports and rebel strength generally mirror those reported above: In models using difference GMM, the coefficients of the interaction terms are identical in direction and significance while imports of major conventional weapons are found to also have an unconditional effect on conflict intensity. When using system GMM, results for major conventional weapons remain the same but those for small arms imports become insignificant. In addition, we re-run our main models employing a number of different specifications. First, we exclude all control variables. Second, we set all cases where no observed arms imports took place to zero and include dummy variables that indicate such zero observations in all models. Third, arms imports may be expected to have their strongest effect in the year(s) after delivery as especially Major Conventional Weapons may necessitate training before being put into action. We thus test how results change when arms imports values are lagged by one year and when they are summed over $t$ and the preceding three, five, and ten years. Fourth, we 
employ standard errors clustered on the conflict level instead of conventional ones to tackle potential heteroscedasticity issues. Sixth, we include an additional measure of government military capability, the quality of government forces as the ratio of military expenditures to military personnel, as done in previous studies of conflict intensity (e.g. Lacina, 2006). Seventh, we use a continuous measure of rebel strength based on the belligerents troop numbers (Wood 2010). And eight, we account for influential observations by omitting potential outliers and employing wild bootstrapping (Roodman et al. 2019). The results of these tests remain consistent with and largely unchanged from those reported in table 2 . This strengthens our confidence that at least in the period following the Cold War, the impact of arms imports on the intensity of intrastate conflict is crucially moderated by the strategic balance of the belligerents' military contest: The death tolls of conflicts involving weak rebels are left unaffected when governments import additional weapons whereas in conflicts fought by capable insurgents, arms import cause intensity to rise and human deaths to multiply.

\section{Discussion and concluding remarks}

While many popular but also academic accounts of the arms trade see it as fuelling intrastate conflict, credible evidence for this relationship is inexistent. An examination of the effect of arms imports on conflict intensity is thus in order. We provide this but challenge the idea that arms imports should have a direct and positive effect on the lethality of armed conflict. Instead, we employ a strategic perspective on combat in this type of conflict and develop the argument that the effect of arms transfers is critically moderated by the balance of power between belligerents. While rebels that challenge the government on equal ground are able to do so via open, conventional combat, weaker rebels have to resort to guerrilla and terrorist tactics while avoiding open engagements. This difference in rebel tactics affects what kind of resources government forces need to defeat them and we posit that because of this, the effect of arms imports is moderated by the balance of power. Facing equally or better endowed rebels, government forces require additional fighting capability. This is provided to them via additional weaponry and there should thus be a positive effect of arms imports on conflict intensity. In contrast, government forces fighting a weaker enemy are already militarily dominant and do not need further fighting capability but instead information on which individuals are enemy combatants and where they hide. Here, governmental arms imports do not help in bringing about or intensifying combat engagements and should thus have no effect on casualty numbers.

Our results support these expectations: we show that when government imports of major conventional weapons and / or small arms coincide with insurgents being militarily equal or 
stronger, the number of casualties increases considerably. In contrast, we do not find any impact of arms imports on the death toll of conflicts where governments are challenged by weak insurgents. These results thus provide partial support for the popular conjecture that arms transfers fuel conflicts but qualify it in an important way: casualty numbers in 9 out of 10 conflicts are actually left unaffected when the government procures arms. However, arms imports $d o$ substantially increase casualty numbers in those conflicts where rebels are strong and combat already very lethal (Balcells and Kalyvas 2014), thus heavily contributing to the bloodiest civil wars. An instrumental variables approach using a novel instrument for small arms also indicates that these results are not due to endogeneity.

These findings illustrate the far-reaching consequences weapons deliveries to governments fighting intense conflicts can have in terms of human bloodshed. They further point to the importance of a critical public tracking of the exporting behaviour of arms producing countries and indicate that multilateral external interventions in the form of arms embargoes and peacekeeping missions play a crucial role in managing and resolving conflict. 


\section{Appendix: Instrumenting for Arms Imports}

Arms imports may be endogenous to conflict intensity as governments may make the import decision in anticipation of intense military campaigns that would result in increased casualty numbers. To tackle this concern, we follow Pamp et al. (2018) in separating Major Conventional Weapons (MCW) into types that may be used in intrastate warfare, e.g. armoured vehicles or aircraft, and types that should be of no use in such conflict, e.g. air defence systems and ships. And we separate small arms (SA) into military weapons and those weapons that have a purely civilian use in hunting or shooting sports. We respectively employ logged imports of MCW unrelated to civil war to instrument for the logged imports of civil war-related MCW, and civilian small arms imports to instrument for imports of military small arms. ${ }^{14}$ For this, we use 2-Stages Least Squares (2SLS) Regression with conflict-fixed effects. Results concerning MCW are presented in table A1 while those for small arms are presented in table A2.

\section{Table Al approximately here}

There, the first two models respectively test for an unconditional effect of the instrumentedfor measure of arms imports while the second two models interact it with the variable accounting for rebel strength. Consistent with our main findings, governmental imports of MCW are found to have no unconditional effect on conflict intensity but one that is conditional on the rebels' capabilities. Imports of major conventional weapons increase casualty numbers in cases where rebels have achieved at least parity but not in the ones where a militarily dominant government fights weaker rebels.

In the case of small arms, imports of military small arms have a small but statistically significant positive effect on conflict intensity even when included in an unconditional way and in conflicts fought against weak rebels. However, this effect doubles in size when governments face rebels that achieve at least parity, thus further corroborating our main results.

\section{Table A2 approximately here}

We report the first stages for these models in tables A3 and A4, respectively. As models A3, A4, A7, and A8 each include two endogenous variables (arms imports and their interaction with rebel strength), we also detail two-first stages for each of these models. These tables also report the results of F-tests for the excludability of individual instruments as well as, for the models where we have two endogenous variables and accordingly two instruments, the Cragg-Donald Statistic (Cragg-Donald 1993). The Null hypothesis for both test statistics is 
that the included instruments are weak, critical values for rejecting this Null are tabulated by Stock and Yogo (2005). All models in tables A3 and A4 indicate that the relevant instruments have a positive and statistically significant effect on the variables to be instrumented for. The dependent and instrumental variables in these models are logged arms import volumes, meaning that e.g. in model A1b, a $10 \%$ increase in the import of non-Civil War MCW is associated with a $1.12 \%$ change in the import of Civil War-related MCW. And the weak instrument tests in table A4, concerning Small Arms, also uniformly reject the Null hypothesis that civilian small arms imports are a weak instrument for military small arms as the values of both the F and the Cragg-Donald Statistics are consistently above those tabulated for having one (or two) of each endogenous and instrumental variables (Stock and Yogo 2005: 101).

\section{Table A3 approximately here}

In contrast, the results of these tests indicate that imports of non-civil war related MCW are a somewhat weak instrument for imports of MCW that can be used in civil war. Most importantly, the Cragg-Donald Statistic for models A3 and A4 respectively only has the values 3.267 and 3.779. Again consulting Stock and Yogo, these values imply that a 5\%-sized test in models A3 and A4 may actually have a rejection rate of up to $25 \%(2005: 88,101)$. However, the coefficient we are interested in, $\beta_{\text {Rebel Strength } x \text { Import: } C W M C W}$, is significant even in a $0.1 \%$-sized test in both models. This should imply that even as our instruments in models A3 and A4 are weak, leading to an inflated rejection rate of the Null that Rebel Strength: EoH x ln Import: Civil War MCW does not affect conflict intensity, this rejection rate should still be relatively small. To explore the statistical significance of the effect of $\ln$ import: Civil War MCW and Rebel Strength: EoH x ln Import: Civil War MCW further, we turn to a weak-instruments robust test of the significance of endogenous regressors in the second stage (see e.g. Andrews et al. 2019). The Anderson-Rubin (AR) test statistic tests "the null hypothesis [...] that the coefficients $\beta_{1}$ of the endogenous regressors $X_{1}$ in the structural equation are jointly equal to zero" (Baum et al. 2007: 491). Importantly, the results of this test are not affected by instrument weakness because "as instruments become weak, the power of the test declines" (ibid.). We report the results of joint and separate AR tests of $\beta_{\text {import: } C W M C W}=0$ and $\beta_{\text {Rebel Strength x Import: } C W M C W}=0$ in table A3.

The results of these tests are very much in line with the "naïve" tests of statistical significance reported along the coefficients in table A1. In models A1 and A2, both the naïve and the weak-instruments robust tests indicate that ln import: Civil War MCW does not affect conflict 
intensity when included unconditionally. And in models A3 and A4, the statistically significant result of the naïve tests on the interaction term Rebel Strength: EoH $x$ ln Import: Civil War MCW and the continued insignificance of ln import: Civil War is mirrored in the AR tests of the instrumented regressors: There is only weak evidence for $\beta_{\text {import: } C W ~ M C W}$ not being zero in models A3 and A4 whereas the Null $\beta_{\text {Rebel Strength x Import: } C W M C W}=0$ is respectively rejected on the $95 \%$ - and $99 \%$-level in these models.

To summarize, the results of our Instrumental Variables analysis of the effect of arms imports on conflict intensity is in line with the results found in the main analysis. Weak instruments tests indicate that Civilian Small Arms imports are not a weak instrument for the import of Military Small Arms. Results from these tests do indicate that the import of non-civil war related MCW may be a weak instrument for imports of $\mathrm{MCW}$ that can be used in civil war. However, results from tests that are robust to weak instruments are in line with the original findings of the Instrumental Variables analysis and hence offer further support for our claim that governmental arms imports increase conflict intensity if rebels are militarily strong.

Table A4 approximately here 


\section{References}

Andrews, Isaiah, James H. Stock, and Liyang Sun. 2019. "Weak Instruments in Instrumental Variables Regression: Theory and Practice." Annual Review of Economics 11: 727-753.

Angrist, Joshua D., and Adriana D. Kugler. 2008. "Rural Windfall or a New Resource Curse? Coca, Income, and Civil Conflict in Colombia." Review of Economics and Statistics 90(2): 191-215.

Arellano, Manuel, and Stephen Bond. 1991. "Some Tests of Specification for Panel Data: Monte Carlo Evidence and an Application to Employment Equations." Review of Economic Studies 58(2): 277-297.

Arellano, Manuel, and Olympia Bover. 1995. "Another Look at the Instrumental Variable Estimation of Error-components Models.” Journal of Econometrics 68(1): 29-51.

Balcells, Laia, and Stathis N. Kalyvas. 2014. "Does Warfare Matter? Severity, Duration, and Outcomes of Civil Wars." Journal of Conflict Resolution 58(8): 1390-1418.

Balli, Hatice Ozer, and Bent E. Sørensen. 2013. "Interaction effects in econometrics." Empirical Economics 45(1): 583-603.

Baum, Christopher F. 2006. An Introduction to Modern Econometrics using Stata. College Station, TX: Stata Press.

Baum, Christopher F., Mark E. Schaffer, and Steven Stillman. 2007. "Enhanced routines for instrumental variables/generalized method of moments estimation and testing." Stata Journal 7(4): 465-506.

Bazzi, Samuel, and Christopher Blattman. 2014. "Economic Shocks and Conflict: Evidence from Commodity Prices.” American Economic Journal: Macroeconomics 6(4): 1-38.

Beck, Nathaniel, and Jonathan N. Katz. 2011. "Modeling Dynamics in Time-Series-Cross-Section Political Economy Data.” Annual Review of Political Science 14: 331-352.

Blanton, Shannon Lindsey. 2000. "Promoting Human Rights and Democracy in the Developing World: US Rhetoric Versus US Arms Exports.” American Journal of Political Science 44(1): 123-31.

Blanton, Shannon Lindsey. 2005. "Foreign Policy in Transition? Human Rights, Democracy, and US Arms Exports." International Studies Quarterly 49(4): 647-68.

Blundell, Richard, and Stephen Bond. 1998. "Initial Conditions and Moment Restrictions in Dynamic Panel Data Models.” Journal of Econometrics 87(1): 115-143.

Bourne, Mike. 2007. Arming Conflict: The Proliferation of Small Arms. Basingstoke: Palgrave.

Brambor, Thomas, William Roberts Clark, and Matt Golder. 2006. "Understanding Interaction Models: Improving Empirical Analyses.” Political Analysis 14(1): 63-82.

Buhaug, Halvard. 2010. "Dude, where's my conflict? LSG, relative strength, and the location of civil war." Conflict Management and Peace Science 27 (2): 107-128.

Buhaug, Halvard, Lars-Erik Cederman, and Jan Ketil Rød. 2008. "Disaggregating Ethno-Nationalist Civil Wars: A Dyadic Test of Exclusion Theory.” International Organization 62(3): 531-551.

Butler, Christopher, and Scott Gates. 2009. "Asymmetry, Parity, and (Civil) War: Can International Theories of Power Help Us Understand Civil War?” International Interactions 35(3): 330-340. 
Caverley, Jonathan D., and Todd S. Sechser. 2017. "Military Technology and the Duration of Civil Conflict." International Studies Quarterly 61(3): 704-720.

Cecco, Leyland. 2018. "Canada selling weapons to Philippines despite human rights concerns." The Guardian 8.2.2018. Available at: https://www.theguardian.com/world/2018/feb/08/canada-combathelicopters-philippines (accessed 1 July 2018).

Cederman, Lars-Erik, and Kristian Skrede Gleditsch. 2009. "Introduction to Special Issue on "Disaggregating Civil War"." Journal of Conflict Resolution 53(4): 487-495.

Chaudoin, Stephen, Zachary Peskowitz, and Christopher Stanton. 2017. "Beyond Zeroes and Ones: The Intensity and Dynamics of Civil Conflict." Journal of Conflict Resolution 61(1): 56-83.

Choi, In. 2001. "Unit Root Tests for Panel Data." Journal of International Money and Finance 20(2): 249-272.

Collier, Paul, and Anke Hoeffler. 2007. "Unintended Consequences: Does Aid Promote Arms Races?" Oxford Bulletin of Economics and Statistics 69 (1): 1-27.

Craft, Cassady, and Joseph P. Smaldone. 2002. "The arms trade and the incidence of political violence in sub-Saharan Africa, 1967-97.” Journal of Peace Research 39(6): 693-710.

Cragg, John G., and Stephen G. Donald. 1993. "Testing identifiability and specification in instrumental variable models." Econometric Theory 9(2): 222-240.

Cunningham, David E., Kristian Skrede Gleditsch, and Idean Salehyan. 2009. "It Takes Two: A Dyadic Analysis of Civil War Duration and Outcome." Journal of Conflict Resolution 53(4): 570-597.

Cunningham, David E., Kristian Skrede Gleditsch, and Idean Salehyan. 2013. "Non-state actors in civil wars: A new dataset." Conflict Management and Peace Science 30(5): 516-531.

Daxecker, Ursula, and Brandon C. Prins. 2017. "Financing rebellion: Using piracy to explain and predict conflict intensity in Africa and Southeast Asia." Journal of Peace Research 54(2): 215-230.

De Boef, Suzanna, and Luke Keele. 2008. "Taking Time Seriously." American Journal of Political Science 52(1): 184-200.

De Juan, Alexander, and Jan H. Pierskalla. 2015. "Manpower to coerce and co-opt-State capacity and political violence in southern Sudan 2006-2010." Conflict Management and Peace Science 32(2): 175-199.

Dube, Oeindrila, and Juan F. Vargas. 2013. "Commodity Price Shocks and Civil Conflict: Evidence from Columbia." Review of Economic Studies 80(4): 1384-1421.

Eck, Kristine 2009. "From Armed Conflict to War: Ethnic Mobilization and Conflict Intensification." International Studies Quarterly 53(2): 369-388.

Erickson, Jennifer L. 2013. "Market imperative meets normative power: human rights and European arms transfer policy.” European Journal of International Relations 19 (2): 209-234.

Fearon, James D. 2007. "Economic Development, Insurgency, and Civil War." In: Institutions and Economic Performance, edited by Elhanan Helpman, 292-328. Cambridge and London: Harvard University Press.

Galula, David. 2006. Counterinsurgency Warfare: Theory and Practice. Westport, CT: Greenwood. 
Garcia, Denise. 2014. "Global Norms on Arms: The Significance of the Arms Trade Treaty for Global Security in World Politics.” Global Policy 5 (4): 425-432.

Gawande, Kishore, Devesh Kapur, and Shanker Satyanath. 2017. "Renewable Natural Resource Shocks and Conflict Intensity: Findings from India's Ongoing Maoist Insurgency." Journal of Conflict Resolution 61(1): 140-172.

Ghobarah, Hzaem Adam, Paul Huth, and Bruce Russett. 2003. "Civil wars kill and maim peoplelong after the shooting stops." American Political Science Review 97 (2): 189-202.

Gleditsch, Kristian Skrede. 2002. "Expanded Trade and GDP Data." Journal of Conflict Resolution 46(5): 712-724.

Greene, Owen, and Nicholas Marsh. 2012. Small Arms, Crime and Conflict: Global governance and the threat of armed violence. London and New York: Routledge.

Heger, Lindsay, and Idean Salehyan. 2007. "Ruthless Rulers: Coalition Size and the Severity of Civil Conflict.” International Studies Quarterly 51(2): 385-403.

Hultman, Lisa, Jacob Kathman, and Megan Shannon. 2014. "Beyond Keeping Peace: United Nations Effectiveness in the Midst of Fighting." American Political Science Review 108(4): 737-753.

Hultman, Lisa, and Dursun Peksen. 2017. "Successful or Counterproductive Coercion? The Effect of International Sanctions on Conflict Intensity." Journal of Conflict Resolution 61(6): 1315-1339.

Kalyvas, Stathis N., and Laia Balcells. 2010. "International System and Technologies of Rebellion: How the End of the Cold War Shaped Internal Conflict." American Political Science Review 104(3): 415-429.

Kiras, James D. 2016. "Irregular Warfare: Terrorism and Insurgency." In: Strategy in the Contemporary World, edited by John Baylis, James J. Wirtz, and Colin S. Gray, 175-194. Oxford: Oxford University Pres.

Knight, Ben. 2017. "Germany's 'deadliest company' pledges to stop selling guns to crisis regions." The Guardian 8.9.2017. Available at: https://www.theguardian.com/global-development/2017/sep/08/ germany-deadliest-company-stop-selling-guns-crisis-regions-heckler-and-koch (accessed 1 July 2018).

Lacina, Bethany. 2006. "Explaining the Severity of Civil Wars." Journal of Conflict Resolution 50(2): 276-289.

Lacina, Bethany. 2009. "Battle Deaths Dataset 1946-2008: Codebook for Version 3.0.” Oslo: PRIO.

Lebacher, Michael, Paul W. Thurner, and Göran Kauermann. 2019. "Censored Regression for Modelling International Small Arms Trading and its" Forensic" Use for Exploring Unreported Trades." arXiv preprint arXiv:1902.09292.

Lu, Lingyu, and Cameron .G. Thies. 2011. "Economic Grievances and the Severity of Civil War." Civil Wars 13(3): 215-231.

Lujala, Paivi. 2009. "Deadly Combat Over Natural Resources: Gems, Petroleum, Drugs, and the Severity of Armed Civil Conflict." Journal of Conflict Resolution 53(1): 50-71.

Lyall, Jason. 2009. "Does indiscriminate violence incite insurgent attacks? Evidence from Chechnya." Journal of Conflict Resolution 53 (3): 331-362. 
Lyall, Jason. 2010. "Are Coethnics More Effective Counterinsurgents? Evidence from the Second Chechen War.” American Political Science Review 104(1): 1-20.

Marshall, Monty G., Ted R.Gurr, and Keith Jaggers. 2016. "Polity IV Project: Political Regime Characteristics and Transitions, 1800-2015: Dataset Users' manual." Vienna, VA: Center for Systemic Peace.

Mehltretter, Andreas., Paul W. Thurner, and Maximilan Scherer. 2019. Do Governmental Weapons Build-ups Prolong or Shorten Intrastate Conflicts? An Instrumental Variable Survival Approach. Paper presented at the Annual Conference of the Midwest Political Science Association Conference, April 4-7, Chicago.

Mehrl, Marius. 2017. "Bargaining with Intensity: Arms and the Signalling of Insurgent Capacity in South Sudan (2005-2016).” FI Working Paper 8. Felsberg: Felsberger Institut für Bildung und Wissenschaft.

Melander, Erik, Therése Pettersson, and Lotta Themnér. 2016. "Organized Violence, 1989-2015." Journal of Peace Research 53(5): 727-742.

Moore, Matthew. 2012. "Selling to Both Sides: The Effects of Major Conventional Weapons Transfers on Civil War Severity and Duration.” International Interactions 38(3): 325-347.

Nordhaus, William, John R. Oneal, and Bruce Russett. 2012. "The effects of the international security environment on national military expenditures: A multicountry study." International Organization 66 (3): 491-513.

Pamp Oliver, Lukas Rudolph, Paul W. Thurner, Andreas Mehltretter, and Simon Primus. 2018. "The Build-up of Coercive Capacities: Arms Imports and the Outbreak of Violent Intrastate Conflicts." Journal of Peace Research 55(4): 430-444.

Perkins, Richard, and Eric Neumayer. 2010. "The organized hypocrisy of ethical foreign policy: Human rights, democracy and Western arms sales." Geoforum 41 (2): 247-256.

Petersohn, Ulrich. 2017. "Private Military and Security Companies (PMSCs), Military Effectiveness, and Conflict Severity in Weak States, 1990-2007." Journal of Conflict Resolution 61(5): 1046-1072.

PRIO. 2017. Norwegian Initiative on Small Arms Transfers: Small Arms Trade Database.

Roodman, David. 2009. "How to do Xtabond2: An Introduction to Difference and System GMM in Stata.” Stata Journal 9(1): 86-136.

Roodman, David, Morten Ørregaard Nielsen, James G. MacKinnon, and Matthew D. Webb. 2019. "Fast and wild: Bootstrap inference in Stata using boottest." Stata Journal 19(1): 4-60.

Schulze, Christian, Oliver Pamp, and Paul W. Thurner. 2017. "Economic Incentives and the Effectiveness of Nonproliferation Norms: German Major Conventional Arms Transfers 1953-2013." International Studies Quarterly 61 (3): 529-543.

SIPRI. 2017. SIPRI Arms Transfers Database. Available at: https://www.sipri.org/databases/ armstransfers (accessed 1 May 2017).

SIPRI. n.d. SIPRI Arms Transfers Database: Sources and Methods, 2. Explanation of TIV tables. Available at: https://www.sipri.org/databases/armstransfers/sources-and-methods\#TIV-tables (accessed 1 May 2017).

Sislin, John, and Frederic Pearson. 2006. "Arms and Escalation in Ethnic Conflicts: The Case of Sri Lanka.” International Studies Perspectives 7(2): 137-158. 
Stock, James H., and Motohiro Yogo. 2005. "Testing for weak instruments in Linear IV regression." In Identification and Inference for Econometric Models: Essays in Honor of Thomas Rothenberg, edited by Donald WK. Andrews and James H. Stock, 80-108. New York: Cambridge University Press.

Valentino, Brandon, Paul Huth, and Dylan Balch-Lindsay. 2004. “'Draining the sea': mass killing and guerrilla warfare.” International Organization 58 (2): 375-407.

Vogt, Manuel, Nils-Christian Bormann, Seraina Rüegger, Lars-Erik Cederman, Philipp Hunziker, and Luc Girardin. 2015. "Integrating Data on Ethnicity, Geography, and Conflict: The Ethnic Power Relations Dataset Family.” Journal of Conflict Resolution 59(7): 1327-1342.

Wilcken, Patrick. 2018. "Britain and the US must stop fuelling the bloody Saudi war on Yemen." The Guardian 20.3.2018. Available at: https://www.theguardian.com/commentisfree/2018/mar/20/yemenarms-saudi-arabia (accessed 1 July 2018).

Wischnath, Gerdis, and Halvard Buhaug. 2014. "Rice or Riots: On Food Production and Conflict Severity across India." Political Geography 43(1): 6-15.

Wood, Reed M. 2010. "Rebel Capability and Strategic Violence Against Civilians." Journal of Peace Research 47(5): 601-614.

Wooldridge, Jeffrey M. 2010. Econometric analysis of cross section and panel data. Cambridge, MA: MIT Press.

Wooldridge, Jeffrey M. 2015. Control Function Methods in Applied Econometrics. Journal of Human Resources 50(2): 420-445.

Wright, Austin L. 2016. "Economic Shocks and Rebel Tactics." HiCN Working Paper 232. Brighton: Institute of Development Studies at the University of Sussex.

Wright, Austin L., Luke N. Condra, Jacob N. Shapiro, and Andrew .C. Shaver. 2017. "Civilian Abuse and Wartime Informing." Pearson Institute Discussion Paper 42. 


\begin{tabular}{|c|c|c|c|c|c|c|}
\hline Variable & & Mean & Std. Dev. & Min. & Max. & Observations \\
\hline \multirow{3}{*}{$\begin{array}{l}\text { Battle } \\
\text { Deaths }\end{array}$} & Overall & \multirow[t]{3}{*}{808.30} & 1919.36 & 25 & 30633 & \multirow{3}{*}{$\begin{array}{l}\mathrm{N}=877 \\
\mathrm{n}= \\
\mathrm{N} / \mathrm{n}=6.70\end{array}$} \\
\hline & \multirow{2}{*}{$\begin{array}{l}\text { Between } \\
\text { within }\end{array}$} & & 1839.20 & 25 & 14490 & \\
\hline & & & 1255.65 & -8641.03 & 16951.30 & \\
\hline \multirow{3}{*}{$\begin{array}{l}\text { In Battle } \\
\text { Deaths }\end{array}$} & overall & \multirow[t]{3}{*}{5.39} & 1.59 & 3.22 & 10.33 & \multirow{3}{*}{$\begin{array}{l}\mathrm{N}=877 \\
\mathrm{n}=131 \\
\mathrm{~N} / \mathrm{n}=6.70\end{array}$} \\
\hline & \multirow{2}{*}{$\begin{array}{l}\text { between } \\
\text { within }\end{array}$} & & 1.28 & 3.22 & 9.36 & \\
\hline & & & 1.00 & .75 & 8.21 & \\
\hline \multirow{3}{*}{$\begin{array}{l}\text { Rebel } \\
\text { Strength: } \\
\text { EoH }\end{array}$} & \multirow{3}{*}{$\begin{array}{l}\text { overall } \\
\text { between } \\
\text { within }\end{array}$} & \multirow[t]{3}{*}{.10} & .30 & 0 & 1 & \multirow{3}{*}{$\begin{array}{l}\mathrm{N}=849 \\
\mathrm{n}= \\
\mathrm{N} / \mathrm{n}=6.74\end{array}$} \\
\hline & & & .34 & 0 & 1 & \\
\hline & & & .17 & -.70 & .90 & \\
\hline \multirow{3}{*}{$\begin{array}{l}\text { Import: } \\
\text { MCW }\end{array}$} & overall & \multirow[t]{3}{*}{374.75} & 667.90 & 0 & 4004.82 & \multirow{3}{*}{$\begin{array}{l}\mathrm{N}=\quad 868 \\
\mathrm{n}=126 \\
\mathrm{~N} / \mathrm{n}=6.89\end{array}$} \\
\hline & \multirow{2}{*}{$\begin{array}{l}\text { between } \\
\text { within }\end{array}$} & & 519.59 & 0 & 2172.94 & \\
\hline & & & 343.36 & -1063.47 & 2440.62 & \\
\hline Import: & overall & \multirow[t]{3}{*}{$2.31 \mathrm{e}+07$} & $1.11 e+08$ & 0 & $1.39 \mathrm{e}+09$ & \multirow{3}{*}{$\begin{array}{l}\mathrm{N}=741 \\
\mathrm{n}= \\
\mathrm{N} / \mathrm{n}=6.68\end{array}$} \\
\hline Small & \multirow{2}{*}{$\begin{array}{l}\text { between } \\
\text { within }\end{array}$} & & $7.75 e+07$ & 0 & $8.11 e+08$ & \\
\hline Arms & & & $5.17 e+07$ & $-4.89 e+08$ & $6.03 e+08$ & \\
\hline \multirow{3}{*}{$\begin{array}{l}\text { ln Import: } \\
\text { MCW }\end{array}$} & overall & \multirow[t]{3}{*}{4.74} & 2.08 & -2.12 & 8.30 & \multirow{3}{*}{$\begin{array}{l}\mathrm{N}=661 \\
\mathrm{n}= \\
\mathrm{N} / \mathrm{n}=5.80\end{array}$} \\
\hline & Between & & 2.00 & -.10 & 7.60 & \\
\hline & Within & & .95 & .17 & 7.74 & \\
\hline ln Import: & Overall & 14.30 & 2.92 & 5.42 & 21.05 & \multirow{3}{*}{$\begin{array}{l}\mathrm{N}=656 \\
\mathrm{n}=103 \\
\mathrm{~N} / \mathrm{n}=6.37\end{array}$} \\
\hline Small & Between & & 2.60 & 7.28 & 20.37 & \\
\hline Arms & Within & & 1.78 & 5.29 & 19.19 & \\
\hline
\end{tabular}

Table 1: Summary Statistics for dependent and main independent variables. Note: "Within" values are computed as deviations from the unit mean and can hence be both positive and negative. 


\begin{tabular}{|c|c|c|c|c|}
\hline & (1) & (2) & (3) & (4) \\
\hline $\begin{array}{l}\text { The Determinants } \\
\text { Of Conflict Intensity }\end{array}$ & $\begin{array}{l}\text { Rebel Strength; } \\
\text { Arms Imports }\end{array}$ & $\begin{array}{l}\text { Interaction } \\
\text { MCW }\end{array}$ & $\begin{array}{l}\text { Interaction } \\
\text { Small Arms }\end{array}$ & $\begin{array}{c}\text { Both } \\
\text { Interactions }\end{array}$ \\
\hline ln Battle Deaths, lagged & $\begin{array}{c}0.422^{* * *} * \\
(8.822)\end{array}$ & $\begin{array}{c}0.389 * * * \\
(8.301)\end{array}$ & $\begin{array}{c}0.404 * * * \\
(8.565)\end{array}$ & $\begin{array}{c}0.385 * * * \\
(8.247)\end{array}$ \\
\hline Year of Conflict & $\begin{array}{c}-0.026 * * * \\
(-3.669)\end{array}$ & $\begin{array}{c}-0.024 * * * \\
(-3.496)\end{array}$ & $\begin{array}{c}-0.025 * * * \\
(-3.633)\end{array}$ & $\begin{array}{c}-0.024 * * * \\
(-3.506)\end{array}$ \\
\hline In Population & $\begin{array}{l}-0.480 \\
(-0.639)\end{array}$ & $\begin{array}{l}-1.056 \\
(-1.433)\end{array}$ & $\begin{array}{l}-0.764 \\
(-1.033)\end{array}$ & $\begin{array}{l}-1.107 \\
(-1.507)\end{array}$ \\
\hline ln GDP, lagged & $\begin{array}{c}0.039 \\
(0.161)\end{array}$ & $\begin{array}{c}0.154 \\
(0.649)\end{array}$ & $\begin{array}{c}0.085 \\
(0.358)\end{array}$ & $\begin{array}{c}0.158 \\
(0.670)\end{array}$ \\
\hline Polity & $\begin{array}{c}-0.041 \\
(-1.612)\end{array}$ & $\begin{array}{l}-0.032 \\
(-1.299)\end{array}$ & $\begin{array}{c}-0.039 \\
(-1.548)\end{array}$ & $\begin{array}{l}-0.033 \\
(-1.320)\end{array}$ \\
\hline Ethnically excluded & 1.158 & 0.787 & 0.481 & 0.471 \\
\hline Population (\%) & (1.609) & $(1.121)$ & $(0.661)$ & $(0.658)$ \\
\hline ln Import: MCW & $\begin{array}{c}0.122 * * \\
(2.541)\end{array}$ & $\begin{array}{l}0.056 \\
(1.151)\end{array}$ & $\begin{array}{l}0.113^{* *} \\
(2.414)\end{array}$ & $\begin{array}{c}0.064 \\
(1.322)\end{array}$ \\
\hline In Import: Small Arms & $\begin{array}{c}0.030 \\
(1.168)\end{array}$ & $\begin{array}{c}0.037 \\
(1.507)\end{array}$ & $\begin{array}{c}0.021 \\
(0.833)\end{array}$ & $\begin{array}{c}0.031 \\
(1.236)\end{array}$ \\
\hline Rebel Strength: Equal or Higher (EoH) & $\begin{array}{l}0.836^{* * *} \\
(2.192)\end{array}$ & $\begin{array}{c}-1.622 * * \\
(-2.555)\end{array}$ & $\begin{array}{c}-4.765 * * * \\
(-3.115)\end{array}$ & $\begin{array}{c}-4.355 * * * \\
(-2.886)\end{array}$ \\
\hline Rebel Strength: EoH x In Import: MCW & & $\begin{array}{c}0.603 * * * \\
(4.763)\end{array}$ & & $\begin{array}{c}0.485^{* * * *} \\
(3.481)\end{array}$ \\
\hline Rebel Strength: EoH x ln Import: Small Arms & & & $\begin{array}{c}0.373 * * * \\
(3.777)\end{array}$ & $\begin{array}{c}0.214 * * \\
(1.994)\end{array}$ \\
\hline Constant & $\begin{array}{c}7.059 \\
(1.145)\end{array}$ & $\begin{array}{c}12.547 * * \\
(2.063)\end{array}$ & $\begin{array}{l}10.103^{*} \\
(1.657)\end{array}$ & $\begin{array}{c}13.219 * * \\
(2.180)\end{array}$ \\
\hline Observations & 405 & 405 & 405 & 405 \\
\hline R-squared & 0.297 & 0.342 & 0.326 & 0.350 \\
\hline Number of conflicts & 65 & 65 & 65 & 65 \\
\hline
\end{tabular}

Table 2. OLS Estimations on battle deaths / year with conflict-fixed effects. Note: GDP = Gross Domestic Product, MCW= Major Conventional Weapons; *** $\mathrm{p}<0.01, * * \mathrm{p}<0.05, * \mathrm{p}<0.1$ 


\begin{tabular}{|c|c|c|}
\hline Import Value & \multicolumn{2}{|c|}{ Battle-Related Deaths } \\
\hline & Rebels: weaker & Rebels: $\geq$ parity \\
\hline \multicolumn{3}{|c|}{ Major Conventional Weapons (TIV) } \\
\hline Sample Mean: & 233 & 642 \\
\hline Sample Mean + one SD: & 274 & 2531 \\
\hline \multicolumn{3}{|c|}{ Small Arms (US\$) } \\
\hline Sample Mean: & 234 & 661 \\
\hline Sample Mean + one SD: & 256 & 1378 \\
\hline
\end{tabular}

Table 3: Predicted number of casualties for arms import values close to sample mean and sample mean + one standard deviation (based on model 4). 


\begin{tabular}{lcccc}
\hline The Determinants & $(\mathrm{A} 1 \mathrm{a})$ & $(\mathrm{A} 2 \mathrm{a})$ & $(\mathrm{A} 3 \mathrm{a})$ & $(\mathrm{A} 4 \mathrm{a})$ \\
Of Conflict Intensity & & & & \\
\hline & & & & \\
Battle Deaths (Lag, LN) & $0.431^{* * *}$ & $0.420^{* * *}$ & $0.419^{* * *}$ & $0.406^{* * *}$ \\
& $(8.671)$ & $(6.763)$ & $(7.448)$ & $(5.856)$ \\
Year of Conflict & -0.009 & $-0.020^{* *}$ & -0.005 & $-0.018^{*}$ \\
& $(-1.242)$ & $(-2.413)$ & $(-0.527)$ & $(-1.886)$ \\
Population (LN) & -0.431 & 0.219 & -0.276 & 0.227 \\
& $(-0.733)$ & $(0.285)$ & $(-0.416)$ & $(0.266)$ \\
GDP (Lag, LN) & 0.134 & 0.006 & 0.173 & 0.066 \\
& $(0.678)$ & $(0.030)$ & $(0.773)$ & $(0.287)$ \\
Polity & -0.016 & -0.021 & 0.012 & -0.001 \\
& $(-0.848)$ & $-0.890)$ & $(0.530)$ & $(-0.053)$ \\
Ethnically excluded & 0.090 & -0.121 & -0.361 & -0.543 \\
Population (\%) & $(0.194)$ & $(-0.303)$ & $(-0.676)$ & $(-1.199)$ \\
ln Import: Small Arms & & 0.020 & & 0.021 \\
(not instrumented) & & $(1.335)$ & & $(1.268)$ \\
Rebel Strength: EoH & 0.215 & 0.406 & $-1.083 * * *$ & $-0.719^{*}$ \\
& $(0.880)$ & $(1.453)$ & $(-2.698)$ & $(-1.768)$ \\
In import: Civil War MCW & -0.187 & -0.211 & -0.423 & -0.419 \\
& $(-0.751)$ & $(-0.850)$ & $(-1.479)$ & $(-1.504)$ \\
Rebel Strength: EoH x ln & & & $0.629^{* * *}$ & $0.562^{* * *}$ \\
Import: Civil War MCW & & & $(4.430)$ & $(4.206)$ \\
Constant & 6.891 & 0.945 & 5.094 & 0.524 \\
& $(1.223)$ & $(0.130)$ & $(0.800)$ & $(0.065)$ \\
Observations & & & & \\
R-squared & 608 & 549 & 608 & 549 \\
\hline Tar Al: & 0.688 & 0.681 & 0.602 & 0.605 \\
\hline
\end{tabular}

Table A1: 2SLS estimation on battle deaths / year with conflict-fixed Effects, second stage estimates. Note: GDP = Gross Domestic Product, MCW= Major Conventional Weapons; *** $\mathrm{p}<0.01, * * \mathrm{p}<0.05, * \mathrm{p}<0.1$ 


\begin{tabular}{|c|c|c|c|c|}
\hline $\begin{array}{l}\text { The Determinants } \\
\text { Of Conflict Intensity }\end{array}$ & (A5a) & (A6a) & (A7a) & (A8a) \\
\hline Battle Deaths (Lag, LN) & $\begin{array}{l}0.415 * * * \\
(9.353)\end{array}$ & $\begin{array}{c}0.412 * * * \\
(9.005)\end{array}$ & $\begin{array}{c}0.412 * * * \\
(9.037)\end{array}$ & $\begin{array}{c}0.408 * * * \\
(8.683)\end{array}$ \\
\hline Year of Conflict & $\begin{array}{c}-0.026 * * * \\
(-3.539)\end{array}$ & $\begin{array}{c}-0.026 * * * \\
(-3.587)\end{array}$ & $\begin{array}{c}-0.027 * * * \\
(-3.665)\end{array}$ & $\begin{array}{c}-0.028 * * * \\
(-3.715)\end{array}$ \\
\hline Population (LN) & $\begin{array}{l}-1.448^{*} \\
(-1.726)\end{array}$ & $\begin{array}{l}-1.454 * \\
(-1.745)\end{array}$ & $\begin{array}{l}-1.654^{*} \\
(-1.945)\end{array}$ & $\begin{array}{c}-1.666 * * \\
(-1.976)\end{array}$ \\
\hline GDP (Lag, LN) & $\begin{array}{l}0.063 \\
(0.298)\end{array}$ & $\begin{array}{l}0.063 \\
(0.300)\end{array}$ & $\begin{array}{c}0.091 \\
(0.423)\end{array}$ & $\begin{array}{c}0.092 \\
(0.429)\end{array}$ \\
\hline Polity & $\begin{array}{c}-0.027 \\
(-1.393)\end{array}$ & $\begin{array}{l}-0.028 \\
(-1.430)\end{array}$ & $\begin{array}{l}-0.018 \\
(-0.882)\end{array}$ & $\begin{array}{c}-0.019 \\
(-0.912)\end{array}$ \\
\hline $\begin{array}{l}\text { Ethnically excluded } \\
\text { Population }(\%)\end{array}$ & $\begin{array}{c}0.590 \\
(1.272)\end{array}$ & $\begin{array}{c}0.590 \\
(1.276)\end{array}$ & $\begin{array}{c}0.519 \\
(1.081)\end{array}$ & $\begin{array}{c}0.517 \\
(1.078)\end{array}$ \\
\hline $\begin{array}{l}\text { Ln import: MCW } \\
\text { (not instrumented) }\end{array}$ & & $\begin{array}{c}0.015 \\
(0.447)\end{array}$ & & $\begin{array}{c}0.016 \\
(0.448)\end{array}$ \\
\hline Rebel Strength: EoH & $\begin{array}{c}0.566^{* *} \\
(2.131)\end{array}$ & $\begin{array}{l}0.571 * * \\
(2.159)\end{array}$ & $\begin{array}{c}-0.422 \\
(-0.724)\end{array}$ & $\begin{array}{c}-0.444 \\
(-0.761)\end{array}$ \\
\hline In import: Military Small Arms & $\begin{array}{c}0.129 * * \\
(2.269)\end{array}$ & $\begin{array}{c}0.127 * * \\
(2.158)\end{array}$ & $\begin{array}{c}0.130 * * \\
(2.228)\end{array}$ & $\begin{array}{c}0.127 * * \\
(2.116)\end{array}$ \\
\hline $\begin{array}{l}\text { Rebel Strength: EoH x ln } \\
\text { Import: Military Small Arms }\end{array}$ & & & $\begin{array}{l}0.116^{*} \\
(1.941)\end{array}$ & $\begin{array}{c}0.120 * * \\
(1.993)\end{array}$ \\
\hline Constant & $\begin{array}{c}16.806^{* *} \\
(2.311)\end{array}$ & $\begin{array}{c}16.904 * * \\
(2.347)\end{array}$ & $\begin{array}{c}18.749 * * \\
(2.544)\end{array}$ & $\begin{array}{l}18.902 * * * \\
(2.596)\end{array}$ \\
\hline $\begin{array}{l}\text { Observations } \\
\text { R-squared }\end{array}$ & $\begin{array}{r}549 \\
0.671 \\
\end{array}$ & $\begin{array}{c}549 \\
0.673 \\
\end{array}$ & $\begin{array}{c}549 \\
0.656 \\
\end{array}$ & $\begin{array}{c}549 \\
0.658 \\
\end{array}$ \\
\hline
\end{tabular}

Table A2: 2SLS estimation on battle deaths / year with conflict-fixed Effects, second stage estimates. Note: GDP = Gross Domestic Product, MCW= Major Conventional Weapons; *** $\mathrm{p}<0.01, * * \mathrm{p}<0.05, * \mathrm{p}<0.1$ 


\begin{tabular}{|c|c|c|c|c|c|c|}
\hline $\begin{array}{l}\text { First Stage: Civil } \\
\text { War MCW }\end{array}$ & $\begin{array}{c}\text { (A1b) } \\
\text { CW MCW }\end{array}$ & $\begin{array}{c}\text { (A2b) } \\
\text { CW MCW }\end{array}$ & $\begin{array}{c}\text { (A3b) } \\
\text { CW MCW }\end{array}$ & $\begin{array}{c}\text { (A3c) } \\
\text { Rebel Str. x } \\
\text { CW MCW }\end{array}$ & $\begin{array}{c}\text { (A4b) } \\
\text { CW MCW }\end{array}$ & $\begin{array}{c}\text { (A4c) } \\
\text { Rebel Str. x } \\
\text { CW MCW }\end{array}$ \\
\hline Battle Deaths & $0.121 * *$ & $0.186 * * *$ & $0.122 * *$ & $\begin{array}{l}0.005 \\
(0.254)\end{array}$ & $0.187 * * *$ & $0.025^{* *}$ \\
\hline \multirow[t]{2}{*}{ Year of Conflict } & $\begin{array}{c}(2.037) \\
0.014\end{array}$ & $\begin{array}{c}(3.150) \\
0.015\end{array}$ & $\begin{array}{l}(2.004) \\
0.014\end{array}$ & $\begin{array}{l}(0.254) \\
-0.002\end{array}$ & 0.015 & 0.002 \\
\hline & $(1.346)$ & $(1.440)$ & (1.344) & $(-0.492)$ & $(1.435)$ & (1.066) \\
\hline \multirow[t]{2}{*}{ Population (LN) } & $1.307^{*}$ & $2.111 * *$ & $1.312^{*}$ & -0.428 & $2.125 * *$ & 0.045 \\
\hline & (1.667) & $(2.468)$ & (1.649) & $(-1.599)$ & $(2.455)$ & $(0.253)$ \\
\hline \multirow[t]{2}{*}{ GDP (Lag, LN) } & 0.237 & -0.042 & 0.236 & 0.099 & -0.044 & -0.050 \\
\hline & $(0.805)$ & $(-0.141)$ & $(0.801)$ & $(0.992)$ & $(-0.146)$ & $(-0.817)$ \\
\hline \multirow[t]{2}{*}{ Polity } & 0.025 & $0.051 *$ & 0.025 & $-0.025^{* * *}$ & $0.050^{*}$ & -0.008 \\
\hline & $(0.916)$ & $(1.822)$ & $(0.910)$ & $(-2.725)$ & $(1.812)$ & $(-1.396)$ \\
\hline Ethnic. excluded & $-1.295^{* *}$ & -0.678 & $-1.293 * *$ & -0.015 & -0.672 & $0.227 * *$ \\
\hline Population (\%) & $(-2.374)$ & $(-1.269)$ & $(-2.359)$ & $(-0.082)$ & $(-1.253)$ & $(2.081)$ \\
\hline ln Import: Small & & 0.025 & & & 0.025 & 0.005 \\
\hline Arms & & (1.355) & & & $(1.356)$ & $(1.295)$ \\
\hline \multirow[t]{2}{*}{ Rebel Strength } & -0.191 & -0.484 & -0.184 & $1.169 * * *$ & -0.465 & $0.858 * * *$ \\
\hline & $(-0.507)$ & $(-1.280)$ & $(-0.449)$ & $(8.465)$ & $(-1.121)$ & (10.181) \\
\hline \multirow[t]{2}{*}{ Non-CW MCW } & $0.112 * *$ & $0.118 * * *$ & $0.112 * *$ & 0.005 & $0.119 * * *$ & 0.001 \\
\hline & $(2.574)$ & $(2.771)$ & $(2.542)$ & $(0.308)$ & $(2.745)$ & $(0.136)$ \\
\hline Rebel Strength $\mathrm{x}$ & & & -0.008 & $1.056 * * *$ & -0.021 & $1.101 * * *$ \\
\hline Non-CW MCW & & & $(-0.041)$ & $(15.105)$ & $(-0.109)$ & $(27.969)$ \\
\hline Constant & $\begin{array}{c}-11.319^{* *} \\
(-2.283)\end{array}$ & $\begin{array}{c}-15.880 * * * \\
(-2.960)\end{array}$ & $\begin{array}{c}-11.360^{* *} \\
(-2.244)\end{array}$ & $\begin{array}{c}2.565 \\
(1.505)\end{array}$ & $\begin{array}{c}-15.986 * * * \\
(-2.929)\end{array}$ & $\begin{array}{l}-0.081 \\
(-0.073)\end{array}$ \\
\hline \multicolumn{7}{|c|}{ Weak instruments tests } \\
\hline F statistic & 6.623 & 7.678 & 3.301 & 118.154 & 3.837 & 403.837 \\
\hline CD Statistic & & & \multicolumn{2}{|c|}{3.267} & \multicolumn{2}{|c|}{3.779} \\
\hline \multicolumn{7}{|c|}{ Anderson-Rubin $\chi^{2}$ weak instruments-robust tests of significance of instrumented variables } \\
\hline Joint Test & 0.63 & 0.83 & \multicolumn{2}{|c|}{$30.02 * * *$} & \multicolumn{2}{|c|}{$27.54 * * *$} \\
\hline CW MCW & 0.63 & 0.83 & \multicolumn{2}{|c|}{2.45} & \multicolumn{2}{|c|}{$2.76^{*}$} \\
\hline $\begin{array}{l}\text { Rebel Strength } x \\
\text { CW MCW }\end{array}$ & - & - & \multicolumn{2}{|c|}{$6.28 * *$} & \multicolumn{2}{|c|}{$6.92 * * *$} \\
\hline Observations & 608 & 549 & 608 & 608 & 549 & 549 \\
\hline R-squared & 0.780 & 0.814 & 0.780 & 0.749 & 0.814 & 0.907 \\
\hline
\end{tabular}




\begin{tabular}{|c|c|c|c|c|c|c|}
\hline $\begin{array}{l}\text { First Stage: Milit. } \\
\text { Small Arms }\end{array}$ & $\begin{array}{c}\text { (A5b) } \\
\text { Milit. SA }\end{array}$ & $\begin{array}{c}\text { (A6b) } \\
\text { Milit. SA }\end{array}$ & $\begin{array}{c}\text { (A7b) } \\
\text { Milit. SA }\end{array}$ & $\begin{array}{c}\text { (A7c) } \\
\text { Rebel Str. x } \\
\text { Milit. SA } \\
\end{array}$ & $\begin{array}{c}\text { (A8b) } \\
\text { Civil war SA }\end{array}$ & $\begin{array}{c}\text { (A8c) } \\
\text { Rebel Str. x } \\
\text { Milit. SA } \\
\end{array}$ \\
\hline Battle Deaths & $\begin{array}{l}-0.317 * * \\
(-2194)\end{array}$ & $\begin{array}{l}-0.346 * * \\
(-2376)\end{array}$ & $\begin{array}{l}-0.332 * * \\
(-2286)\end{array}$ & $\begin{array}{c}-0.049 \\
(-0789)\end{array}$ & $\begin{array}{l}-0.365 * * \\
(-2493)\end{array}$ & $\begin{array}{c}-0.058 \\
(-0.024)\end{array}$ \\
\hline Year of Conflict & $\begin{array}{c}0.007 \\
(0.256)\end{array}$ & $\begin{array}{c}0.003 \\
(0.126)\end{array}$ & $\begin{array}{c}0.006 \\
(0.225)\end{array}$ & $\begin{array}{c}0.010 \\
(0.923)\end{array}$ & $\begin{array}{c}0.002 \\
(0.080)\end{array}$ & $\begin{array}{c}0.009 \\
(0.829)\end{array}$ \\
\hline Population (LN) & $\begin{array}{c}9.465 * * * \\
(4.560)\end{array}$ & $\begin{array}{c}9.127 * * * \\
(4.377)\end{array}$ & $\begin{array}{c}9.450 * * * \\
(4.552)\end{array}$ & $\begin{array}{l}1.660^{*} \\
(1.876)\end{array}$ & $\begin{array}{c}9.086 * * * \\
(4.358)\end{array}$ & $\begin{array}{l}1.562^{*} \\
(1.755)\end{array}$ \\
\hline GDP (Lag, LN) & $\begin{array}{c}-0.763 \\
(-1.029)\end{array}$ & $\begin{array}{l}-0.740 \\
(-0.999)\end{array}$ & $\begin{array}{c}-0.772 \\
(-1.041)\end{array}$ & $\begin{array}{c}-0.289 \\
(-0.912)\end{array}$ & $\begin{array}{c}-0.749 \\
(-1.011)\end{array}$ & $\begin{array}{c}-0.282 \\
(-0.892)\end{array}$ \\
\hline Polity & $\begin{array}{c}-0.085 \\
(-1.246)\end{array}$ & $\begin{array}{l}-0.093 \\
(-1.356)\end{array}$ & $\begin{array}{c}-0.085 \\
(-1.240)\end{array}$ & $\begin{array}{c}-0.076 * * * \\
(-2.615)\end{array}$ & $\begin{array}{c}-0.093 \\
(-1.357)\end{array}$ & $\begin{array}{c}-0.079 * * * \\
(-2.682)\end{array}$ \\
\hline Ethnic. excluded & $-4.523 * * *$ & $-4.395 * * *$ & $-4.643 * * *$ & 0.013 & $-4.525^{* * *}$ & 0.045 \\
\hline $\begin{array}{l}\text { Population (\%) } \\
\text { ln Import: MCW }\end{array}$ & $(-3.482)$ & $\begin{array}{c}(-3.381) \\
0.169 \\
(1.505)\end{array}$ & $(-3.557)$ & $(0.023)$ & $\begin{array}{c}(-3.467) \\
0.181 \\
(1.605)\end{array}$ & $\begin{array}{c}(0.080) \\
0.049 \\
(1.011)\end{array}$ \\
\hline Rebel Strength & $\begin{array}{c}-0.252 \\
(-0.271)\end{array}$ & $\begin{array}{c}-0.191 \\
(-0.205)\end{array}$ & $\begin{array}{c}-0.872 \\
(-0.771)\end{array}$ & $\begin{array}{l}5.314 * * * \\
(11.016)\end{array}$ & $\begin{array}{c}-0.904 \\
(-0.800)\end{array}$ & $\begin{array}{l}5.305 * * * \\
(10.997)\end{array}$ \\
\hline Sport SA & $\begin{array}{c}0.248 * * * \\
(4.983)\end{array}$ & $\begin{array}{c}0.241 * * * \\
(4.825)\end{array}$ & $\begin{array}{c}0.238 * * * \\
(4.683)\end{array}$ & $\begin{array}{l}-0.052 * * \\
(-2.394)\end{array}$ & $\begin{array}{c}0.229 * * * \\
(4.482)\end{array}$ & $\begin{array}{c}-0.054 * * \\
(-2.493)\end{array}$ \\
\hline $\begin{array}{l}\text { Rebel Strength } \\
\text { x Sport SA }\end{array}$ & & & $\begin{array}{c}0.123 \\
(0.963)\end{array}$ & $\begin{array}{c}0.631 * * * \\
(11.554)\end{array}$ & $\begin{array}{c}0.143 \\
(1.113)\end{array}$ & $\begin{array}{c}0.636 * * * \\
(11.598)\end{array}$ \\
\hline Constant & $\begin{array}{c}-59.767 * * * \\
(-4.565)\end{array}$ & $\begin{array}{c}-57.370 * * * \\
(-4.356)\end{array}$ & $\begin{array}{c}-59.427 * * * \\
(-4.537)\end{array}$ & $\begin{array}{l}-10.559^{*} \\
(-1.891)\end{array}$ & $\begin{array}{c}-56.807 * * * \\
(-4.311)\end{array}$ & $\begin{array}{l}-9.854^{*} \\
(-1.751)\end{array}$ \\
\hline Weak Instruments & & & & & & \\
\hline $\begin{array}{l}\text { F statistic } \\
\text { CD Statistic }\end{array}$ & 24.827 & 23.279 & \multicolumn{2}{|c|}{12.850} & \multicolumn{2}{|c|}{12.165} \\
\hline $\begin{array}{l}\text { Observations } \\
\text { R-squared }\end{array}$ & $\begin{array}{c}549 \\
0.733\end{array}$ & $\begin{array}{c}549 \\
0.735\end{array}$ & $\begin{array}{c}549 \\
0.734\end{array}$ & $\begin{array}{c}549 \\
0.843\end{array}$ & $\begin{array}{c}549 \\
0.735\end{array}$ & $\begin{array}{c}549 \\
0.843\end{array}$ \\
\hline
\end{tabular}

Table A4: 2SLS estimation on battle deaths / year with conflict-fixed Effects, first stage estimates. Note: GDP = Gross Domestic Product, MCW= Major Conventional Weapons; *** $\mathrm{p}<0.01, * * \mathrm{p}<0.05, * \mathrm{p}<0.1$ 

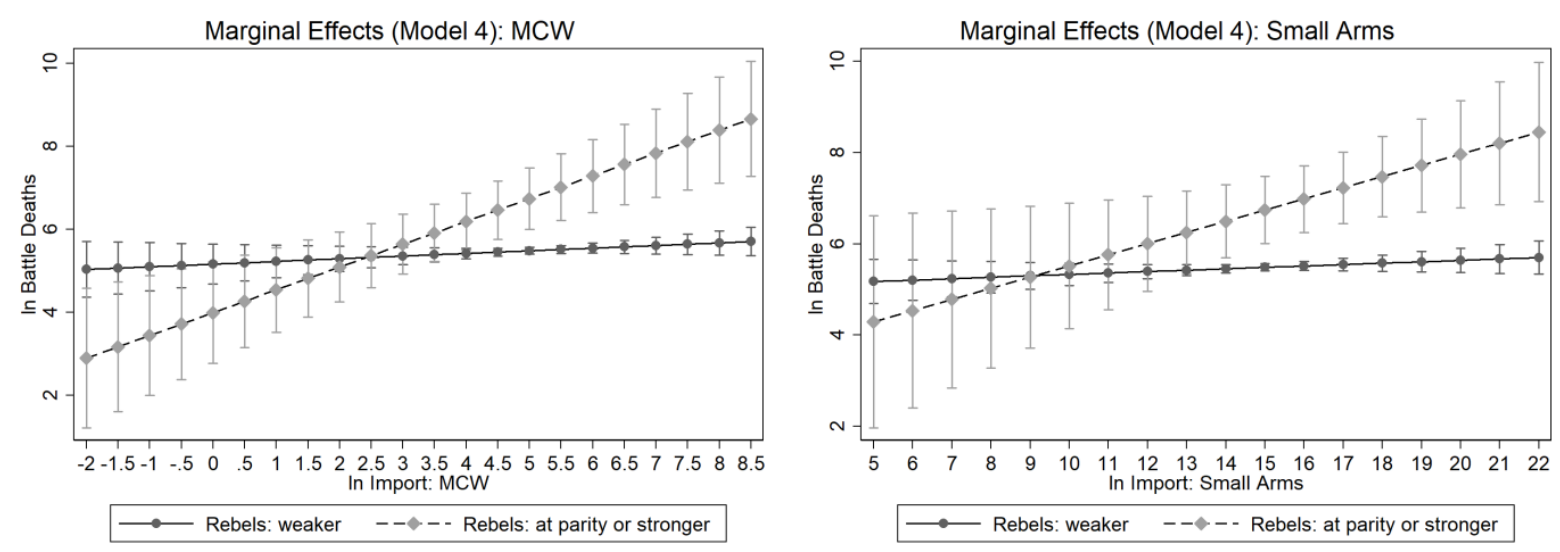

Figure 1: Marginal effects for the interactions Rebel Strength $x$ Import: $M C W_{t}$ and Rebel Strength $x$

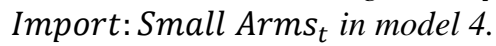




\section{Endnotes:}

\footnotetext{
${ }^{1}$ There are good reasons to expect that arms transfers also affect a conflict's overall lethality in other ways. We note below that our theoretical framework implies that this may be the case for indiscriminate violence against civilians. In addition, transferred arms may contribute to conflicts' lethal long-term effects (see Ghobarah et al. 2003) by e.g. increasing availability of arms to criminals who are willing to use them or causing poisonous pollution in the groundwater people drink and use to cook. However, we focus on fighting lethality in this article. ${ }^{2}$ See Table A3 in the appendix for a regression table replicating Moore's (2012) analyses of conflict intensity using both his original variable and the corrected version to measure the logged government imports of weapons during the conflict and in the five years before it. We thank Maximilian Scherer for indicating this error.

${ }^{3}$ There is some empirical evidence that governments challenged by rebels using guerrilla tactics engage in largescale violence (Valentino et al. 2004; Downes 2008). However, they do so by targeting the civilian population and producing non-combatant casualties while combat events are left unaffected or even decrease (Lyall 2009).

${ }^{4}$ This expectation is supported by findings that countries increase military spending when perceiving security threats (Collier and Hoeffler 2007; Nordhaus, Oneal and Russet 2012).

${ }^{5}$ For more information on TIVs, see SIPRI (n.d.).

${ }^{6}$ The appendix also includes a table reporting summary statistics for all variables used here.

${ }^{7}$ This was verified in personal communication with Kristian Gleditsch. Belligerents' troop sizes could arguably be a function of conflict intensity, not the other way around. However, our variable does not measure total troop numbers but their ratio, is coded for conflict spells, not months or years, and conflict intensity played no role in coding it. Thus, Rebel Strength should be unaffected by the number of battle-related deaths and well-suited to test our theoretical argument as substantial manpower is a condition for being able to use conventional tactics while also making the use of guerrilla ones less feasible (Butler and Gates 2009; Balcells and Kalyvas, 2014). The NSA data also report an estimate of rebels' troop numbers which can be used to construct a continuous measure of relative rebel strength (Wood 2010). Results using this measure are reported in the appendix and are in line with our main results.

${ }^{8}$ Missings include seven years from the conflict between the government of Myanmar and the NSCN-K, three each from the conflicts between Israel and Fatah and Azerbaijan and the self-declared republic of NagornoKarabakh, and two from the conflict between the government of Bangladesh and the PBCP-J. Remaining missing observations concern single conflict years in Indonesia, Senegal, and Tajikistan, among others.

${ }^{9}$ Due to SIPRI and NISAT using different units of observation, we cannot produce a unified measure of imported arms. We do not report results for models including only one type of transferred weapon here but in the appendix as they do not substantially differ from those obtained in models using both types.

${ }^{10}$ The coefficient for Rebel Strength: EoH exhibits a significant and strong negative effect in models three and four but is substantially meaningless on its own. This constituent term measures the effect insurgents being at least as militarily capable as the government has on conflict intensity given that the logged import of small arms is zero. As reported in table 2, all countries in our sample import some non-zero amount of logged small arms.

${ }^{11}$ These are 4.5 and 7 logged TIV for MCW and 14 and 17 logged US\$ for Small Arms.

${ }^{12}$ We do so by setting all other independent variables to Pakistan's observed 2009 values when using Stata's margins command. Setting all right-hand variables to Pakistan's values results in a predicted 5681 battle deaths, close to the actual 2009 death toll of 6303.

${ }^{13}$ These findings are also robust to using a control function approach instead of instrumental variables (see e.g. Wooldridge 2015). See the appendix for results.

${ }^{14} 1$ is added to import volume before taking the logarithm to avoid missing values.
} 